Dept. of Food Hygiene,

Faculty of Vet. Med.. Assiut University,

- Head of Dept. Prof. Dr. T.A. El-Bassiony.

\title{
ESTIMATION OF SOME INDUSTRIAL POLIUTANTS IN MILK AND MILK PRODUCTS (With 7 Tables)
}

\author{
By \\ NAGAH M. SAAD; TH.A. IBRAHIM *; A. SHEHATA* \\ and A.SH. SEDDEK*
}

(Received at 22/10/1989)

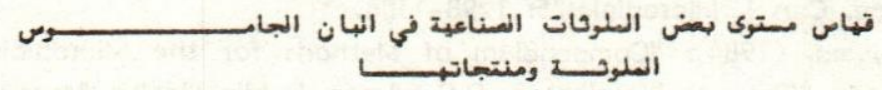

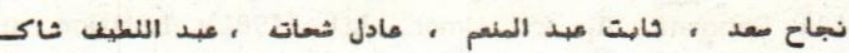

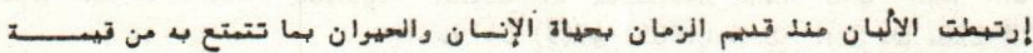

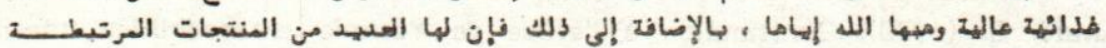

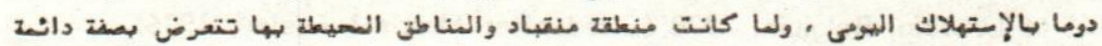

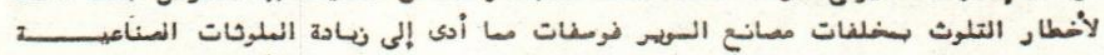

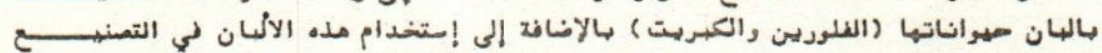

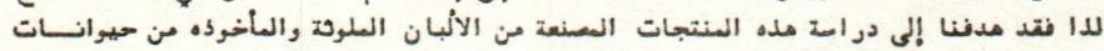

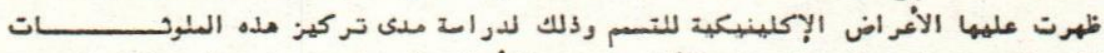

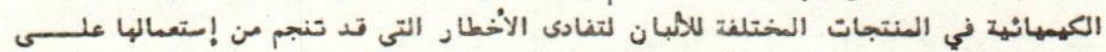

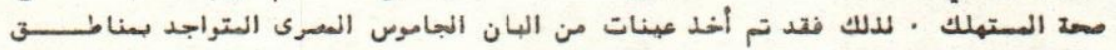

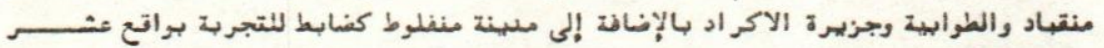

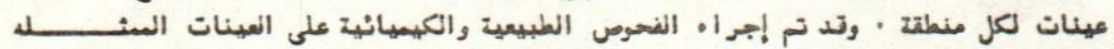

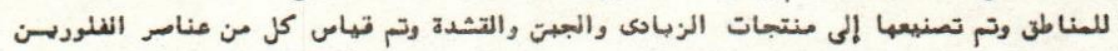

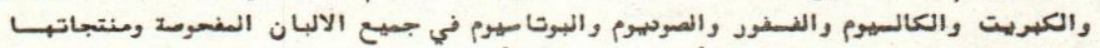

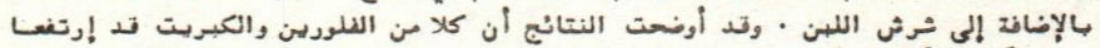

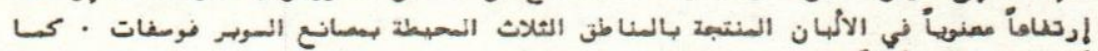

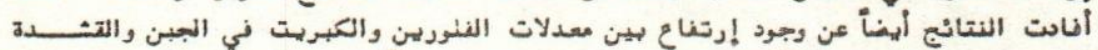

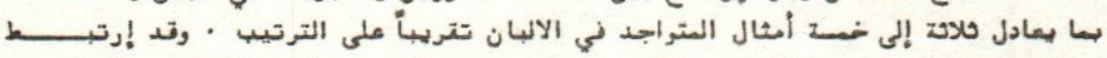

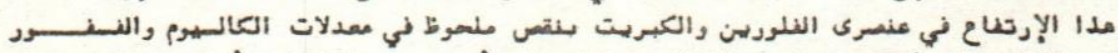

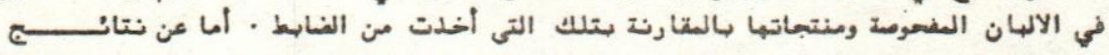

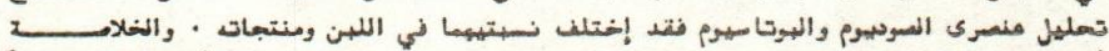

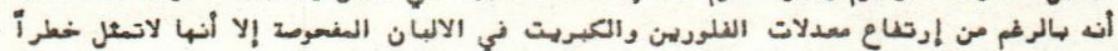

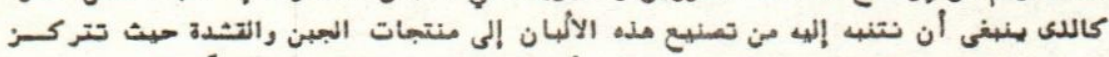

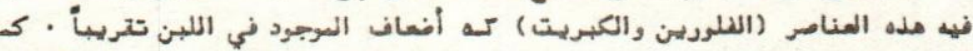

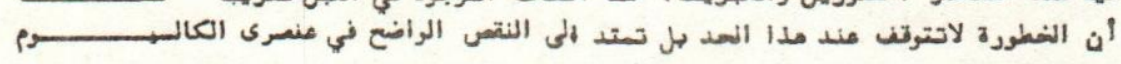

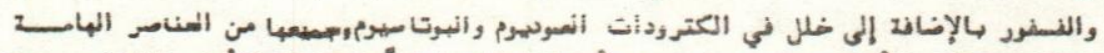

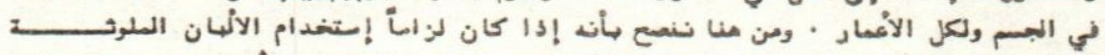

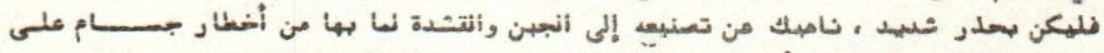

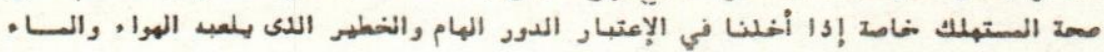

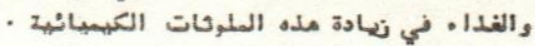

* : Dept. of Medicine, Fac. of Vet. Med., Assiut University.

Assiut Vet_Med.]. Vol. 23, No. 46, July, 1990. 
NAGAH SAAD, et al.

SUMMARY

The present study estimate the levels of sulphur and fluorine in buffaloe's milk and their products in three localities (Manquabade, El-Tawabiya and El-Akrad) surrounding the superphosphate factory in Assiut governorate. Related elements as calcium phosphorus, sodium and potassium were also investigated.

The physical examination (colour and flavour) revealed that all examined milk samples were within normal limits. The chemical examination showed a significant decrease in chloride and fat perecentage. Statistical analytical results indicated a significant increase of sulphur (at 0.01 level) in milk, whey, cheese and yoghourt of the three examined areas. Moreover, a significant elevation of fluorine level was recorded in all milk samples and their products, accompanied with significant depletion in both calcium, phosphorus, and sodium, and increase in potassium level.

\section{INTRODUCTION}

Contamination of food supply by environmental pollutants is recieving an increasing attention. Attention has been focused on milk, particulary since it is nearly almost the perfect single food stuff as it contains high quality animal protein, butter fat and performed vitamins as well as its richness in minerals specially calcium and phosphorus. In addition to the elements that occur in milk in a relatively large proportions there are a large number of elements usually measured in ppm or ug per litre and reffered as trace elements e.g. copper, cobalt and fluorine. Fluorine is highly reactive element occures in soil, water and forage contaminated with fluorine as an air pollutant from various fluoride emitting industries. Fluorine has been widely reported as a prophylactic agent in the pervention of dental caries.

Interest in the biological significance of fluoride was at first confined to its toxic effects upon animals, following the discovery of chronic endemic fluorosis of man and farm stock in several countries in 1931. The most serious outbreaks of fluorosis are of industrial origin resulting from contamination of pastures byfluorine compounds emitted by industrial factories such as aluminum and superphosphate factories (TAWERS, 1954).

Transfer of fluorine across the mammary giand barrier appears to be smal!. In endemic fluorisis areas, or where the cows ration has been supplemented with fluorine to moderate levels, values within the normal range and appreciably higher have both been reported in milk (HARVEY, 1952). Evidence has a!so been produced that suckling rats and pupies subsisting on the milk of fluoride fed mothers accumulate more fluorine in their bodies than do similar animals consuming the miik of mothers on normal diets (MAPLESDEN, et al. 1960).

Assiut Vet.Med.h, Vol. 23, No. 46, July 1990. 
The total fluoride levels in milk from cows grazing in fluoride contaminated pastures are found to be about twice as high as those in milk from cows on a normal grass (GRREC and PLEBIN, 1986).

DUTOIT, et al. (1937) showed definite indications, that fluorine disturbs the normal metabolism of both calcium and phosphorus.

In subsequent study, IBRAHIM, et al. (1985) recorded the contamination of the environment at the areas surrounding the super-phosphate plant at Manquabade by both fluorine and sulphur. The high sulphur levels in animals feed affected the mucous membranes, gastro-intestinal tract,and central nervous system (WHITE, 1964).

As milk is life food for both newly born animals as well as for human consumption, therefore this study aimed to investigate, to what extent industrial pollution affects milk and milk products constituents (fluorine, sulphur, calcium, phosphorus, sodium and postassium) from buffaloes rearing in the areas surrounding the superphosphate plant Manquabade.

\section{MATERIAL and METHODS}

Three localities, (El-Akrad, El-Tawabiya and Manquabade) were studied and the fourth area (Manfaloute) was considered as control. Ten individual milk samples (2 litres each), representing 10 animals, from buffaloes were collected from every locality.

The samples were dispatched to the laboratory without delay and examined physically for colour and flavour (APHA, 1972), chemically for $\mathrm{pH}$ value using $\mathrm{pH}$ meter (Orion Model 701) equipped with standard electrode. Fat percentage was determined by the method of Gerber (A.P.H.A. 1972). Chloride percentage was done after LING (1963). Lactose percentage (Benedict method) was determined after HARVEY and HILL (1967). Then each milk sample was divided into equal 4 portions, the first three were manufactured according to the method of FAHMY and SHARARA (1950) to cheese and that of LAMPERT (1975) to cream and yoghourt. The fourth portion was used as original milk.

The original milk samples and milk products (cheese, cream and yoghourt) and milk by product (whey) were used for estimation of sulphur (STOCKHOLM and KOCH, 1923), calcium (BETT and FRASER, 1959), sodium and potassium (PEACH and TRACY, 1960), phosphorus (MORINL and PROX, 1973) and fluorine (KROOK and MAYLIN, 1979).

\section{RESULTS}

The physical examination (colour and flavour) of all milk samples were within normal limits.

The results of chemical examination, of milk for flourine, sulphur, phosphorus, calcium, potassium and sodium contents were recorded in tables 1, 2, 3, 4, 5, 6 and 7 , respectively. 
NAGAH SAAD et al.
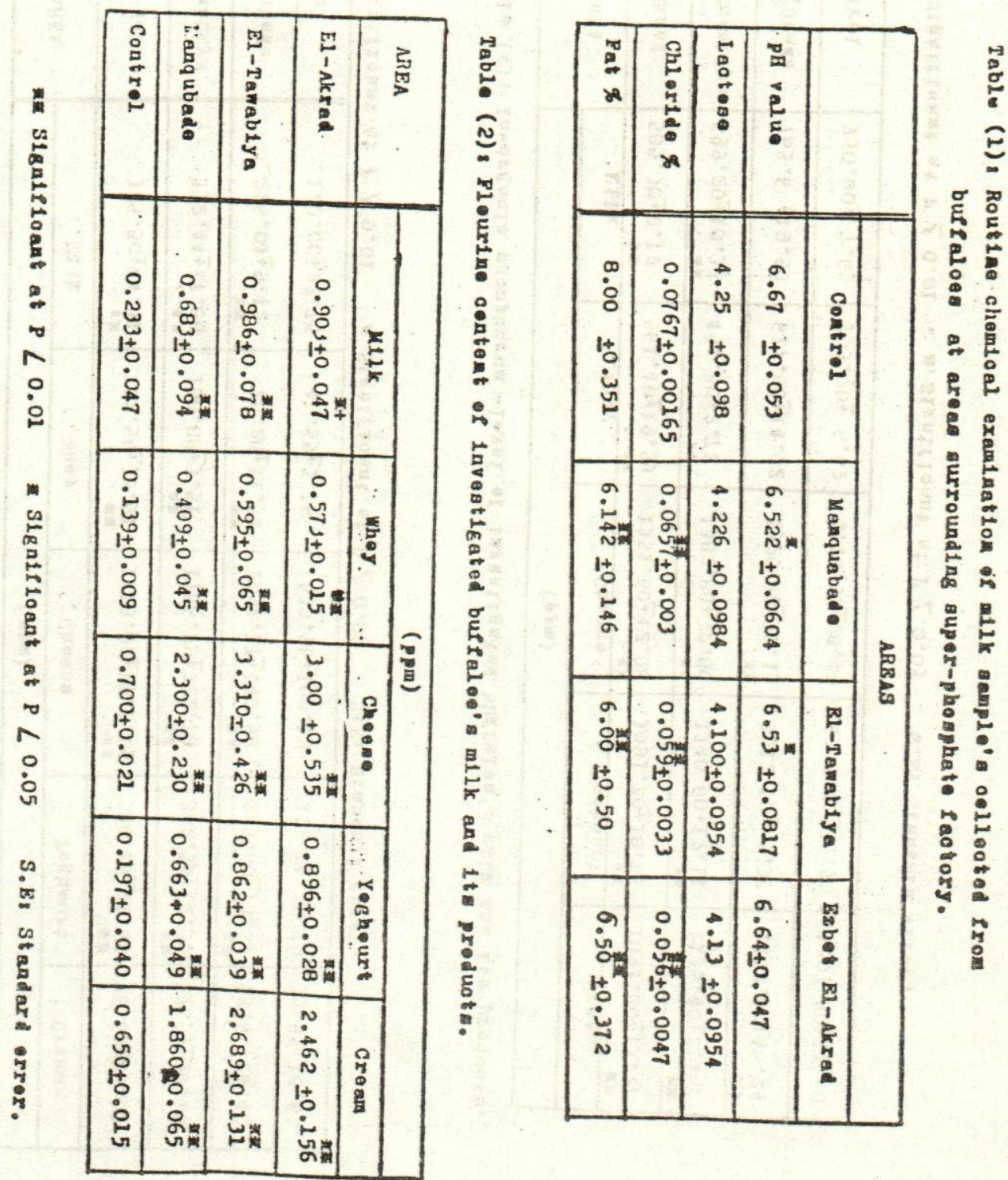

Assiut Vet.Med.J.Vol. 23, No. 46, July, 1990. 
INDUSTRIAL POLLUTANTS IN MILK
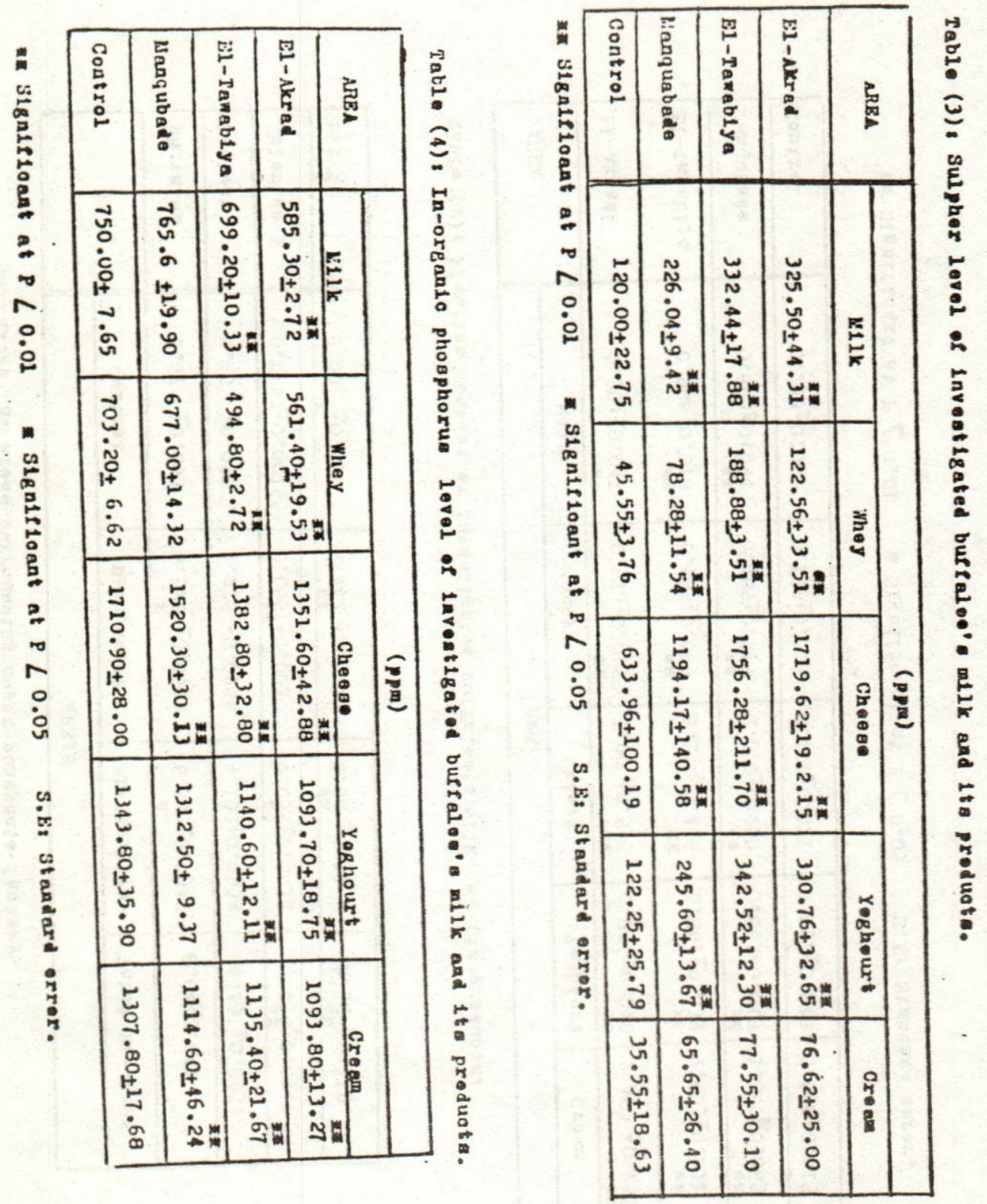

Assiut Vet.Medu.Vol. 23, Na. 46, July, 1990. 
NAGAH SAAD et al.

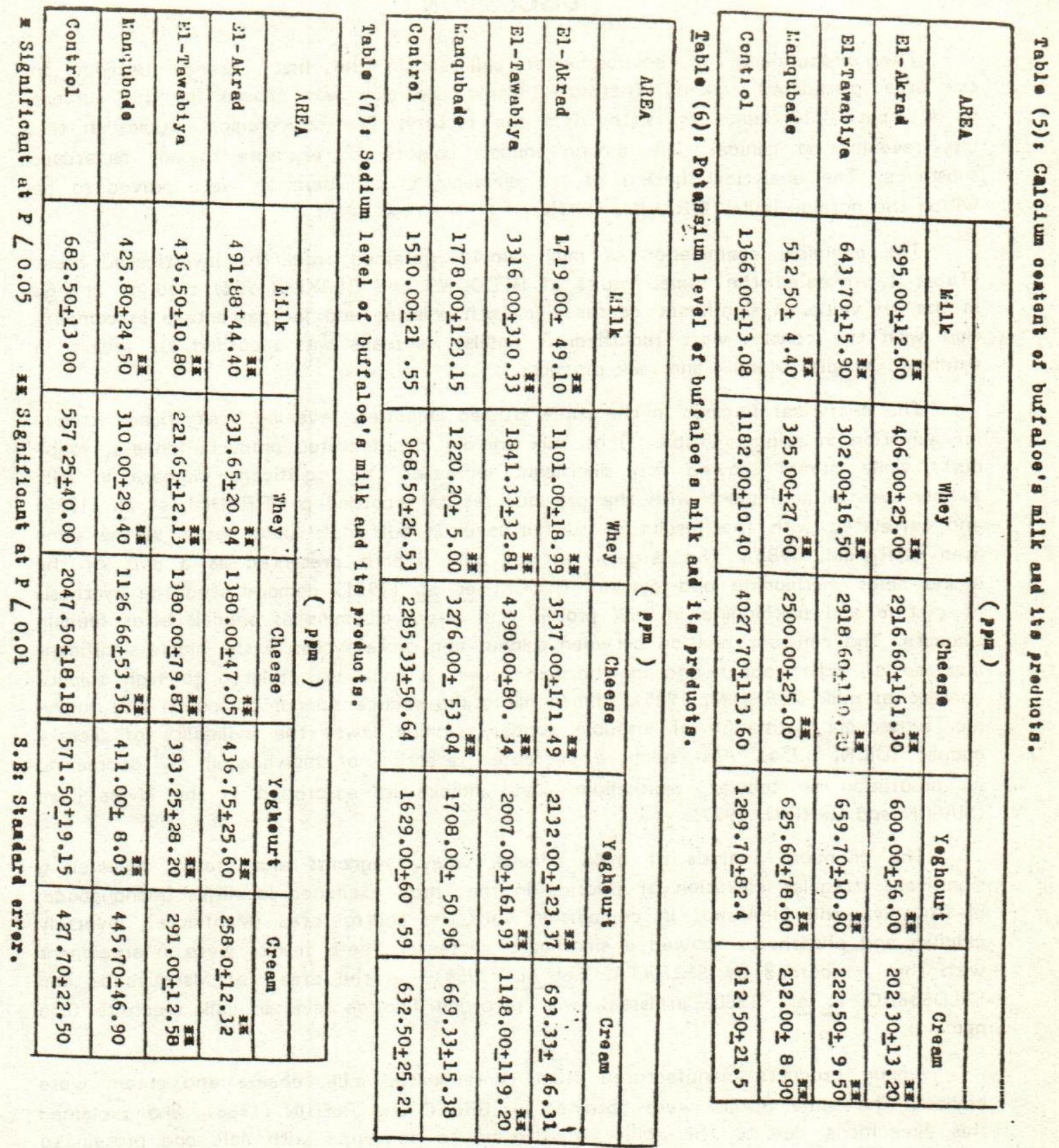




\section{NAGAH SAAD, et al.}

\section{DISCUSSION}

The measurments of environmental pollutants, in the first instance depends on the area considered control. Therefore, Manfaloute city was chosen for this purpose as it located 18 kilmeters north from the factory. The toxicological studies in this city revealed no clinical signs among animals pointing to exposure to any hazardous substance. The analytical finding of the elements in consideration were proved to be within the normal limits (IBRAHIM, 1983).

The chemical examination of milk samples obtained from the investigated areas (Table 1) revealed the same results of BEDDOWS and BLAKE (1982) that no change in the $\mathrm{pH}$ value. A significant decrease in both chloride and fat percentage in comparison with the control were recorded. A simillar decrease was recorded for sodium in examined samples of milk and milk products.

The analytical findings in the three studied localities, revealed a significant irregular elevation in sulphur (Table 3) of milk and its menufactured products (cheese, yoghourt) while cream showed non significant increase. The significant increase in milk sulphur was in agreement with the previous results recorded by IBRAHIM, et al. (1985) and correlated with the resuits of sulphur level in buffaloe's blood serum in the same area (IBRAHIM, 1983). The largest part of milk sulphur presented as a part of the amino acids methionine and cystine. BLOCK, et al. (1951) demonstrated the synthesis of cystine and methionine in milk protein and serum albumins of animals after feeding sulphate. The constant relation between sulphur and protein clarify the highly significant increase of both copper and molybdenum levels in milk was related to high sulphur content of milk (IBRAHIM, 1985). Rumen microflora reduce sulphur compound into sulphide, subsequent formation of insouble copper sulphide lower the avilability of dietary copper (DICK, 1954). Also sulphate decreases retention of molybdenum by decreasing its absorption by tubular epithelium and inhibits its absorption in the lower ilium (MASON and CARDIN, 1977).

The chemical analysis of milk, cheese, whey, yoghourt and cream, revealed a significant irregular elevation of fluoride in the three examined localities (Manquabade, El-Tawabiya and El-Akrad) in comparison with the control area (Manfloute). Inversely calcium and phosphorus showed a significant decrease. These results were in agreement with that recorded by SHEHATA, et al. (1984) in the area of Manquabade and SHLOSBERG, et al. (1980) in Israel, who recorded fluoride level in milk reach to 0.34 ppm.

Among products manufactured from contaminated milk, cheese and cream were highest. The same results were obtained by GRREC and PLEBIN (1986), who explained this phenomena due to the ability of fluorine to compined with lipid and protein to form a complexed compounds.

Assiut Vet.Med.l, Vol. 23, No. 46, July 1990. 


\section{INDUSTRIAL POLLUTANTS IN MILK}

Inspite of the previously recorded by BEDDOWS and BLAKE (1982) that the addition of fluoride to milk not affect calcium and phosphorus levels, oppositely our results revealed a marked significant decrease in both elements (tables 4, 5). There is a corresponding decrease of calcium and phospharus in buffaloe's blood serum accompanied by significant intensive rates of excretion. Moreover, fluoride is able to withtrap calcium in urinary excretion even if it highly significant decreased in serum. Phosphates is seriously decreased in serum but not excreted in urine in excess. This could indicate the direct reiationship of the three elements. The previous information explain the difference between addition of fluoride to milk in vitro and the metabalism of it inside the animal body in relation to calcium and phosphorus.

In conclusion, the investigation of milk and its products revealed a high concentration of the two pollutants (fluorine and sulphur) specially in cheese 3 to 5 folds of milk. Also, in cream fluoride level was 3 folds of milk. It is deemiy necessary to warning about the hazardous effects of these pollutants on both newly born animals and human being in the studied areas. The consuming of such milk and their products considered as an additional source of exposure beside the direct sources of air and water. Moreover, the effect of infant requirements may contribute through distributing the levels of calcium, phosphorus, sodium and potassium in vital foods like milk and milk products.

\section{REFERENCES}

A.P.H.A. (1972): "Standard methods for the examination of dairy products". 13th ed., American Public Health Association, Washington, D.C.

Beddows, C.G. and Blake, C. (1982): The statjs of fluoride in bovine milk. II. The effect of various heat treatment processes. J. Fd. Technol. 17, 63-70. Bett, I.M. and Fraser, C.P. (1959): Determination of calcium in serum Clin. Chem. Acta.,
4, 364.

Block, R.J.; Stekol, J.A. and Loosil, J.K. (1951): Synthesis of sulphur amino acids from inorganic sulphate by ruminants. Arch. Biophys. 33, 353.

Dick, A.T. (1954): Preliminary observations on the effect of high intake of molybdenum and inorganic sulphate on blood copper and on fleece. in crossbred sheep. Aust.
Vet. J. 30, 197.

Dutoit, P.I.; Snuts, D.B. and Halon, A.I. (1937): Studies in mineral metabolism XXXV!Fluroine metabolism in rats and bovine. J. of Veterinary Sience and Animal Industry. B, 2, 359. Fahmy, A.H. and Sharara, H.A. (1950): Studies on Egyptian Domiati cheese J. Dairy
Res., 17, 312.

Grrec, J.P. and Plebin, R. (1986): Repartition du fluor dans les differents products laitiers obtenus a partir de lait contamine. The science of the total Environment, 50,183. Harvey, J.M. (1952): Chronic endemic fluorosis of Marino sheep in Queensland. J. Agric.
Sci., 9, 47: 141.

Assiut Vet.Med.1., Vol. 23, No. 46, July 1990. 


\section{NAGAH SAAD, et al.}

Harvey, W.C. and Hill, H. (1967): Milk production and control 4th ed. H.K. Léwis and Co., London.

Ibrahim, Th.A. (1983): Toxicological effects of the byproduct, of the superphosphate plant on Egyptian buffaloes in Assiut province. Ph.D. Thesis presented to the Faculty of Vet. Med., Assiut Univ.

Ibrahim, Th.A.; Shehata, A. and Shaaban, A.A. (1985): Effect of industrial pollution on mineral content of cow's and buffaloe's milk. J. Egypt. Vet. Med. Ass., 45, $1,539$.

Krook, L. and Maylin, G.A. (1979): "Industrial fluoride pollution, chronic fluoride poisoning in con. Island cattle". Corneal Veterinarian, 69 (3-supple 8), 70 pp.

Lampert, L.M. (1975): Modern dairy products. 3rd ed. chemical publishing camp., INC New York.

Ling, T.R. (1963): "Textbook of dairy chemistry". Vol. II, 3rd Ed., P.l. 30, Champan and Hall, London.

Maplesden, D.C.; Motzok, l.; Oliver, W.T. and Branion, H.D. (1960): Fluorine in animal tissues and fluids. J. Nutr. $71,70$.

Mason, J. and Cardin, C.J. (1977): The compostion of molybdate and sulphate ions for a transport system in the ovine small intestine. Res. Vet. Sci., 36, 1205.

Morinl, L. and Prox, J. (1973): New and rapid procedure for serum phosphorus using O-phenylenediamine reductiant. Clin. Chem. Acta, 46, 113: 117.

Peach, K. and Tracy, M.V. (1960): Flame photometric method for sodium, potassium and calcium. Modern methods of plant analysis. Willians and Twine (eds) Vol. V. springer-Verlage, Berlin.

Shehata, A.; lbrahim, Th.A. and Shabaan, A.A. (1984): Effect of industrial pollution of mineral content of cow's and buffaloe's milk. First scientific congress, Fac. Vet. Med., Assiut University.

Shlosberg, A.; Bartama, U. and Egyed, M.N. (1980): Flurosis in dairy cattle due to high fluoride rock phosphate supplement. J. Fluoride 13 (2): 57-69.

Sotckhoim, M. and Koch, F.C. (1923): Quantitative method for the determination of total sulphur in biological material J. Am. Chem. Spc. 45, 1953.

Towers, R.G. (1954): Chronic fluoride poisoning associated with industry. Vet. Rec., Vol. 6, 354.

White, B.J. (1964): Sulphur poisoning in ewes. Vet. Rec. 76 (10), 278-279.

Assiut Vet.Med.l, Vol. 23, No. 46, July 1990. 